\title{
Опір тоталітарній системі як ключова тема автобіографічно-мемуарного дискурсу українських шістдесятників
}

\begin{abstract}
Kasyan Lyudmyla, Opir totalitarnij sistemi jak ključova tema avtobiografičnomemuarnogo diskursu ukrainskih šistdesjatnikiv (Resistance to the Totalitarian System as a Key Theme of the Memoir-Autobiographical Discourse of the Sixties). „Poznańskie Studia Slawistyczne" 6. Poznań 2014. Publishing House Science and Innovate, pp. 119-128. ISBN 978-83-63795-51-1. ISSN 2084-3011.

Some European nations and countries stayed in the area of totalitarianism for a long time. This fact and various ways of transforming and self-identity in a totalitarian society require careful studying in a broad scientific spectrum. Studying of the dissident movement is one of the important aspects of this multifaceted research topic. Resistance movement against totalitarianism in the second half of the twentieth century on the territory of Ukraine is closely linked with the concept of Ukrainian sixties. The place and understanding of the role in the cultural and political opposition to totalitarianism, features and images of the sixties are considered through memoir texts as social, political and aesthetic phenomenon of sixties. Self-reception of representatives of the rebellious generation gives the important information about forms and manifestations of resistance for understanding the phenomenon of the sixties, its place in the spiritual coordinates of the twentieth century.
\end{abstract}

Keywords: Ukraine; autobiography; memoir; sixties; resistance movement; generation and cultural phenomenon

Шістдесятництво - знакове явище української історії другої половини XX століття. Саме із ним асоціюється виникнення опозиції до одного із найжорстокіших тоталітарних режимів XX століття. Із шістдесятництва, яке об’єднало широке коло творчих особистостей, почався український рух опору, учасники якого прагнули зняти етнокультурну деформацію, сконсолідувати націю. 
Проблематиці українського шістдесятництва та українському рухові опору присвячено ряд літературознавчих, історичних, культурологічних досліджень, зокрема, праці Л. Тарнашинської, Н. Зборовської, О. Зарецького, О. Пахльовської, Л. Медведєвої, Ю. Курносова, Г. Касьянова, Б. Захарова та багатьох інших. Можна говорити про дискурс шістдесятництва, який має широку критичну рецепцію. Та, незважаючи на це, наявні дослідження не вичерпують такої глибокої й багатовекторної теми. Літературознавець і літературний критик Л. Тарнашинська зазначає: „шістдесятництво й досі залишається terra incognita - якщо мати на увазі його як явище в усіх взаємообумовленостях і зв'язках" (Тарнашинська 2008: 154).

Глибшому осмисленню шістдесятництва сприяють мемуари, автобіографії, есеїстика самих шістдесятників. Пройшовши складні життєві й творчі випробування, продовжуючи працювати в XXI столітті, в новій історичній парадигмі, вони з позиції теперішнього висловлюють своє бачення суті й природи феномену шістдесятництва. Своєрідність цього погляду полягає в тому, що грунтується він не на наукових дослідженнях, а на живому світлі особистої пам'яті.

2.

Автобіографічні й мемуарні твори шістдесятників становлять значний масив корпусу української мемуаристики кінця XX початку XXI століття. Найбільш репрезентабельними зразками є Спогади і роздуми на фінішній прямій І. Дзюби, Книга споминів М. Коцюбинської, Ното feriens I. Жиленко, Шістдесятники поза пафосом Р. Корогодського, Люди не зі страху С. Кириченко, 3 незнищенного племені Дон Кіхотів Н. Світличної, Коловорот М. Плахотнюка, Один із шістдесяти М. Горбаля, На березі часу, Сад житейських думок, трудів та почуттів В. Шевчука.

Шістдесятницьким мемуарам властивий жанровий синкретизм: власне мемуари (спогади про різні події та людей, які зустрічалися на життєвому шляху) сполучаються із художньою автобіографією (розповіддю про події власного життя, становлення своєї особистості). У творах тісно переплітаються два принципи зображення: мемуарний 
- відтворення певних історичних подій, ситуацій, людей, настроїв, i автобіографічний - фокусування уваги на власній постаті, життєвих колізіях, думках і почуттях. Ці два підходи створюють органічну цілісність, оскільки для авторів властиве „усвідомлення себе частинкою колективної історії і долі”. Твори відзначається також складністю структури тексту, який включає авторську оповідь, роздум, опис, різноманітні інтертектуальні елементи.

Варто зауважити, що всі мемуаристи, автори вищезазначених текстів, самопозиціонуються як представники одного покоління, окреслюють його „персональний склад” і свою вписаність у нього.

У всіх автодокументальних текстах автобіографічно-мемуарного дискурсу українських шістдесятників у тематичній площині можна виділити кілька ключових, досить традиційних проблемно-тематичних пласти:

- історія суспільства, своєрідність історичного часу, образ доби;

- історія автобіографічного героя (власного „я”), розкриття психологічного та ідейного формування особистості під впливом історичних подій та близьких людей, формування естетичних поглядів, громадянського самовизначення автобіографічного героя, творчу історію написаних ним творів;

- образ сучасників, друзів, вчителів.

Своєрідною темою, цих текстів, є тема опору тоталітарній системі. Вона виявляється, як у соціокультурному, так і особистісно-психологічному аспекті.

Опір, бунт (внутрішній, зовнішній) як категорія справжності існування у несправжньому, сфальсифікованому тоталітарному світі, 3 позиції сьогодення (часу написання текстів) у авторів здебільшого асоціюється, збігається 3 поняттям шістдесятництво. У нашому дослідженні ми зупинимося, лише на мікротематичному окресленні цього унікального явища в автобіографічно-мемуарному дискурсі українських шістдесятників.

Автори спогадів у різній мірі піднімають тему виникнення, „термінологічного" означення, творчого спрямування і значення шістдесятників для майбутніх поколінь. Так, на думку Є. Сверстюка, поява шістдесятників „можливо, детермінована потоком утрат: на очах покоління все втрачало значення і сенс; людина втрачала лице і будь- 
-яку вагу; слово вивітрювалось; мова засмічувалася і зневажалася; ріки висихали; культура і література спрофановувались" (Сверстюк 1993: 26).

Назва, означення „шістдесятники”, за спостереженнями мемуаристів, зробилося усталеним значно пізніше, в перспективі часу: „Ми не знали, що ми шістдесятники. Це вже потім з дистанції часу виникло таке означення. А тоді, повторюю, це була когорта молодих талановитих людей, які входили в життя, не знаючи, що вони входять в історію" (Дзюба 2011: 147). У 60-70-х роках XX ст. це поняття у провладному офіційному дискурсі фігурувало з негативною конотацією, як зазначає I. Жиленко, „термін «шістдесятники» тільки народжувався і вживався переважно із негативним забарвленням нашими недругами в одному ряду з іншими ярликами: «піротехніки», «штукарі», «верлібристи», «космічно-гіперболічні» поети тощо" (Жиленко 2011: 428).

Мемуаристи наголошують на тому, що шістдесятники - не течія, i тим паче - не школа, перш за все, - це люди, які зважилися на протест, „духовний бунт”, стали в опозицію до існуючої тоталітарної системи, пройшовши духовну еволюцію, змогли звільнитися від нав'язуваних нею ідеологем:

Шістдесятники - спонтанний вияв духовного дозрівання, нового мислення, нової системи цінностей, нового осмислення національного досвіду в надрах тоталітарної системи. Вони виховувалися саме в ній, у цій системі, несучи на собі родимі плями середовища, яке їх породило, перейшовши різні стадії його усвідомлення. Коли ж на хвилі післякультівського оновлення відкрився колосальний масив нових відомостей, відкрилася прихована Правда, мали мужність 3 піднятим заборолом піти ій назустріч - і будувати своє життя вже за новими критеріями, згідно з велінням цієї Правди (Коцюбинська 2006: 276).

У мемуарних текстах висловлюється твердження про те, що шістдесятництво - це рух опору, в якому дух бунтарства і дух солідарності, високий моральний імператив об’єднував абсолютно різних людей, як за родом діяльності, так і за творчим спрямуванням.

Наша солідарність виходила 3 почуття, із серця. Ми просто любили один одного. Кожна людина була самоцінна у цьому русі. Хтось старший, хтось молодший. Це не питання покоління, це радше питання плеяди, когорти. При тому кожен залишався особистістю. Копій не було (Дзюба 2011: 147). Нас усіх об'єднувала жага знань 
і самовираження через активну діяльність, творчість і чітко усвідомлений як абсолют вимір моральності. У світі, наскрізь фальшивому, тлінному, деформованому, моральність стала паролем (Корогодський 2009: 35).

Поступово із поширенням вживання i збільшенням часової перспективи означення „шістдесятники” змінювало своє оцінне забарвлення. І. Дзюба зазначає, що воно почало стосувався тих представників нового покоління, які стали в більш чи менш виражену опозицію

до рутинного стану речей, до панівних поглядів і шукали нових шляхів у мистецтві та правдивого розуміння суспільних проблем, не зупиняючись перед критикою політичного режиму. Поняття „шістдесятник”, „шістдесятництво” асоціювалися 3 певним еталоном громадянської сміливості, інтелектуальної незалежності й етичної відповідальності (Дзюба 2008: 511),

але вже в XXI столітті, на думку автора, воно із суспільно-оцінювального стало хронологічним.

Апелюючи до тези сучасних дослідників українського шістдесятництва, які розглядають дилему: „шістдесяті - це естетичний прорив, чи переважно політичне явище?”, самі шістдесятники наполягають на тому, що такий поділ є вельми помилковим, оскільки шістдесятництво - явище і естетичне, і політичне. У зв'язку з цим Л. Костенко у автобіографічному інтерв'ю акцентує увагу на тому, що тоталітарна система не обмежується лише політичною площиною, вона демонтує культуру, нищить естетику, тому

шістдесятники у мистецтві були дисидентами у політиці. Природно, що вони протистояли системі. Мистецький і політичний протест - це були дві складові одного цілого. I не мистецький процес починався з політичного, а навпаки. Художник не міг жити в тих умовах, він задихався. I навіть політична боротьба була наповнена моральним, культурним змістом насамперед (Дзюба 2011: 147).

Окрім авторських роздумів і узагальнень рух опору в шістдесятницькому мемуарно-автобіографічному дискурсі відтворюється через численні деталі повсякдення, подробиці конкретного людського життя. Невід'ємною частиною щоденного життя постають різноманітні форми протесту й супротиву тоталітарному режиму, в них тісно переплітаються естетичні настанови і громадсько-політичні вимоги. Автори 
детально розповідають про участь у несанкціонованих офіційною владою літературно-мистецьких заходах, зокрема літературних вечорах, диспутах, лекторіях 3 історії України, участь у роботі опозиційного творчого громадського об’єднання - Клубу творчої молоді „Сучасник” (КТМ), описують акції протесту, зокрема, спогади про таку знакова подію (однин із перших відкритих політичних протестів у СРСР) як виступ у кінотеатрі „Україна” 5 вересня 1965 р. на прем’єрі фільму C. Параджанова Тіні забутих предків присутні у багатьох мемуарноавтобіографічних текстах. Автори відтворюють, як сам їі перебіг, так і психологічний стан учасників, власні відчуття і мотивацію дій.

Важливою складовою опозиційного руху постає зі спогадів самвидав. Мемуаристи зазначають свою причетність до цього процесу, називають прізвища найпоширеніших авторів, розповідають про специфіку розповсюдження самвидавних творів. Наприклад, Н. Світлична, згадує:

У 60-х роках брала жваву участь у самвидавному процесі: передруковувала більші й менші не цензуровані твори („Більмо” М. Осадчого, публіцистику Є. Сверстюка, I. Дзюби, В. Чорновола, збірки віршів М. Вінграновського, І. Драча, Л. Костенко, Б. Мамайсура, І. Сокульського, М. Холодного та ін.), редагувала спогади Д. Шумука, перефотографовувала архів Симоненка, їздила з магнітофонними записами його не цензурованих віршів до шкіл, бібліотек і сільських клубів на Харківщині й Луганщині, виступала на вечорах із самвидавних творів. Усе це стало приводом до арешту 18 травня 1972 р. (Світлична 2008: 46).

На сторінках спогадів відтворюються і різні форми ідеологічноадміністративного переслідування: позбавлення роботи, виключення 3 вузів, „обробка” на партійних та комсомольських зборах, розпуск Клубу творчої молоді, заборона зборів коло пам'ятника Шевченку в Києві, „профілактичні” виклики в КДБ, які тривали десятки років, та ін. Розповідається і про дві хвилі арештів у різних містах України: наприкінці серпня 1965 р. та на початку 70-х рр. У спогадах I. Дзюби, Н. Світличної, С. Кириченнко описуються процедура і технологія затримання та арешту, перебування в слідчому ізоляторі КДБ. Перед читачем постає радянська політична тюрма зі своїми законами, побутом, ієрархією стосунків і цінностей, методами роботи і засобами впливу, а із Різдвяного спогаду Н. Світличної, Людей не зі страху С. Кириченко через власні спогади та введення інтертекстуальних елементів 
(листів та спогадів інших) постає ще одна „реалія”, „світ у світі” - радянський табір, зона для політичних в'язнів.

Автори показують механізми тиску від затримання до ув'язнення (прихований і відкритий нагляд, процедура неодноразових обшуків, вилучення літератури, очні ставки, перехресні допити, інспіровані, фальшиво-наклепницькі свідчення), роботу радянського суду, а також методи нищення і зламу особистості в таборах та на засланні: тяжка фізична праця, вилучення листів, позбавлення побачень із рідним, принизливі процедури особистого обшуку. Опис цього автори здійснюють за допомогою ретельно виписаних деталей, фіксації щоденних побутових реалій та епізодів, „картинок” тодішнього соціального і суспільно-політичного життя. Такий підхід у висвітлення подій минулого і відтворенні дисидентського опору сприяє дегероїзації обох конфліктуючих сторін - індивіда і режиму, переводить оповідь із площини пафосної авторської оповіді про власну участь у дисидентського русі у свідчення про епоху тоталітаризму і невідворотний особистісний вибір, межову ситуації, яка так чи інакше тяжіє над кожною людиною, що живе в заблокованому суспільстві.

Надзвичайно важливим та інформативним постає у спогадах психологічний самоаналіз авторів, свідчення про перехід і перебування в становищі радянського в'язня, психологічне проходження лабіринтом моральних пасток і вибір власної позиції, свідчення про постійну духовну роботу над виробленням внутрішньої свободи.

Говорячи про складність і багатогранність шістдесятництва як явища політичного і естетичного водночас, про взаємодоповнення і взаємонаснаження цих категорій, мемуаристи не заперечують, що в українському русі опору наприкінці 60 -х років XX століття окреслюються своєрідні „центри тяжіння”: мистецько-літературний і політичний. Вони не були чітко розмежовані. Ці „виміри”, „орбіти” постійно перетиналися, накладалися одна на одну.

Наближеність авторів до кожного з цих центрів, більша чи менша міра входження в ту чи іншу орбіту позначається і на тематичному діапазоні творів, точніше на акцентах у висвітленні форм і виявів бунту, осмисленні місії шістдесятників у радянському тоталітарному суспільстві. Так, у спогадах С. Кириченко, Н. Світличної, М. Плахотнюка більше уваги приділено заходам суспільно-політичного протесту: 
створення комітетів по захисту тих чи інших політв'язнів (наприклад, Ніни Строкатої), утворення політичних організацій (Української Гельсінської Групи), написання листів протесту проти порушення прав людини в СРСР, антиукраїнської політики, створення філософсько-політичних праць (Право жити Юрія Бадзя), розповідається про українське дисидентське середовище, порівнюється дисидентський рух у колишніх радянських республіках, зокрема Литві, Росії, аналізується взаємозв'язки московського і українського дисидентського кола, точки дотику та розходження. Подаються портрети-характеристики друзів, знайомих дисидентів-політв'язнів та міркування про їхню роль у відстоюванні національної самобутності та демократичних прав свого народу. На переконання авторів, саме присутність у тоталітарному суспільстві „людей не зі страху”, наявність опозиції стала в майбутньому підмурівком у справі національного відродження, побудові незалежної держави.

Представники „тихого”, „літературного” шістдесятництва I. Жиленко, В. Шевчук детальніше зупиняються на особливостях культурнонаціонального руху та літературного процесу в умовах тоталітаризму. Фокусують увагу на проблемі митець і режим. Висвітлюють протистояння митців-шістдесятників як носіїв нових виражальних засобів, справжніх естетичних цінностей, нового світогляду і партійно-ідеологічної цензури. На переконання мемуаристів, реалізація чесного письменницького покликання, служіння високому мистецтву, це теж своєрідна опозиція тоталітаризму, своєрідна етико-естетична форма бунту:

Не були ми борцями. Але були людьми і письменниками. Не бунтувались активно, але писали чесно Тютюнник. Шевчук, Вінграновський, Ліна Костенко, Макаров... Ціла когорта львівських письменників. Нас було немало. Отих, що не просто сиділи в ямі, а ще й творили справжні національні і людські цінності (Жиленко 2011: 702).

I. Жиленко з позицій часу так формулює значення і місію, насамперед, „літературного” шістдесятництва:

Ми лише підтримували вогонь у час, коли вогонь майже нікому не був потрібен. У цьому наша історична місія. Щоб вогонь не погас зовсім. Колись прийдуть інші і докірливо запитуватимуть: „Чому у ваш час вогонь був такий слабий?”. Але не дати вогню погаснути - це теж вимагає чийогось життя (Жиленко 2011: 721). 
3.

Література особистого документа привертає пильну увагу дослідників, читачів, авторів можливістю через призму особистісного погляду осягнути світовідчуття людини XX ст., глибше зрозуміти соціальні і культурні процеси, висловити ставлення до свого часу, представити себе самого.

Автобіографічно-мемуарний дискурс українських шістдесятників представляс ще однин погляд на свосрідність європейського, антитоталітарного руху другої половини XX століття. Презентує свідчення учасників руху опору про форми і прояви опозиції на українському грунті. Мемуари та автобіографії українських шістдесятників $\epsilon$ вдячним матеріалом для подальших гуманітарних, постколоніальних студій.

\section{Література}

Дзюба I., 2008, Спогади і роздуми на фінішній прямій, Київ.

Дзюба I., 2011, С поети для епох, Київ.

Жиленко I., 2011, Homo feriens, Київ.

Корогодський Р., 2009, Брама світла: Шістдесятники, Львів.

Коцюбинська М., 2006, Книга споминів, Київ.

Сверстюк Є., 1993, Блудні сини Украӥни, Київ.

Світлична Н., Світличний І., 2008, 3 живучого племені Дон Кіхотів, Київ.

Тарнашинська Л., 2008, Презумпиія доџільності: Абрис сучасної літературознавчої концептології, Київ. 
